\title{
Determining the knowledge of food safety and purchasing behavior of the consumers living in Turkey and Kazakhstan
}

\author{
Nevin Sanlier ${ }^{1 \star}$, Ayhan Dağdeviren, Bülent Çelik, Saniye Bilici and Aktolkin Abubakirova \\ Department of Nutrition and Dietetics, Faculty of Health Science, Gazi University, Ankara, Turkey.
}

Accepted 18 August, 2011

\begin{abstract}
Complete and balanced nutrition with reliable food consists of the basis of health and protective health services. Therefore, the current study was carried out to determine the knowledge of food safety level and purchasing behavior of 668 consumers living both in Turkey $(n=348)$ and in Kazakhstan $(n=320)$ and to compare the results. Volunteered consumers for the research were given a face to face interview between March and September 2010. It was found that the knowledge of purchasing behavior $(14.43 \pm 2.56)$ of food safety $(20.82 \pm 4.20)$ of the consumers living in Turkey was higher compared to those living in Kazakhstan (11.84 $\pm 2.92,14.74 \pm 3.86$ respectively) and that the difference between the two countries was statistically significant $(p<0.01)$. In addition, a positive correlation was found between knowledge of food safety and purchasing behavior $(r=0.541, p<0.01)$; age and purchasing behavior $(r=0.325, p<0.01)$ and knowledge score of food safety $(r=0.148, p<0.01)$.
\end{abstract}

Key words: Purchasing behavior, knowledge of food safety, consumer, Turkey, Kazakhstan.

\section{INTRODUCTION}

Food-borne diseases constitute a common public health at a global scale. Every year, millions of people worldwide die and many are hospitalized from foodborne diseases and illnesses as a result of consumption of contaminated food (Knight et al., 2003).

World governments concentrate their efforts on improving food safety, in order to promptly and properly respond to the increasing types and incidents of foodborne diseases. Food-borne infections are placed in the core of primary community health concerns, by both advanced and developing countries of the world (Baş, 2004; Eren, 2007). While it is hard to predict the actual number of incidents of food-borne diseases, it is a known fact that many lives were lost to diarrhea caused by food and water-borne microbiological agents, tolling around 1.8 million minors during 1998 and 2.1 million people, during 2000, in the developing world (except China). In industrial states of the world, on the other hand, it is stated that every one individual in a group of three is

*Corresponding author. E-mail: ntekgul@gazi.edu.tr nevintekgul@gmail.com. Tel: + 903122162604. affected by food-borne diseases each year and almost $30 \%$ of the population in advanced countries are presented with food-borne diseases (Baş, 2004). In the US, approximately 76 million incidents of food-borne diseases are reported to take place in average during any year, where 325,000 people are institutionalized, and 5,000 ending up dead (Mead et al., 1999; WHO, 2002). There have been 29,901 cases of Salmonella paratyphii infection, 21,068 cases of dysentery and 8,824 cases of Hepatitis-A infections in 2004, Turkey, according to the data supplied by the Ministry of Health. Data available on food-borne diseases and food poisoning fail to reflect the actual situation, as there is not any statutory requirement in effect, for the reporting of food-borne or related diseases, in Turkey (Sanlier, 2009). Research made on recorded incidents of food poisoning among the consumer public in Kazakhstan, revealed no relevant data.

The economic outcomes of food contamination and food-borne diseases are presumed to be in a range of 3.3 to 12 million dollars for the US, as attributable to pathogens, generating some 6.5 to 35 billion dollars cost for the central government, on an annual basis, as a result of food-borne diseases, during 1995. The five 
major food-borne epidemics that occurred in England and Wales in 1996 were predicted to cost 300 to 700 million pounds sterling, including medical treatment costs and claims associated with deaths throughout these disasters. Predictions state that every 1 out of 10 persons in the UK or 1 out of 12 people in the US suffer from food-borne diseases each year, entailing to dramatic financial troubles (Redmond and Griffith, 2003). The predicted annual cost of 11,500-days of food poisoning cases for Australia has been calculated to be 2.6 million Australian Dollars (WHO, 2002). The customers represent the final link in the food safety chain. The purchasing power and level of awareness of the consumers is an important factor for ensuring food safety (Alpuğuz et al., 2009). The poor hygienic treatment of food during storage, processing and preparation may help creation of an environment suitable for bacterial growth, including the fast and easy spreader species such as Campylobacter, Salmonella and other infectious agents (Baş et al., 2006). Many people are poisoned from day to day, for consuming food produced in nonhygienic environments, lacking sufficient knowledge or training on hygiene, using unclean water or due to inefficient storage conditions, lack of cleaning or mixing of chemicals with foodstuffs (Sanlier, 2009).

Food can be mishandled at many places during food preparation, handling and storage and several studies indicate that consumers have inadequate knowledge about procedures needed to prevent foodborne illnesses at home (Mederios et al., 2001; Meer and Misner, 2000; Redmond and Griffith, 2003; Woodburn and Raab, 1997). The prevention of foodborne illnesses requires educating food consumers on safe food handling practices (Jevsnik, Hlebec and Raspor, 2008). However, prior to education, it is important to assess food safety issues relevant to consumers. It has been demonstrated that level of education affects the level of knowledge or awareness in any casual consumer, in combination with age, sex and level of income (Angelillo et al., 2000; Redmond and Grifith, 2003; Bermudez-Millan et al., 2004; Mitkakis et al., 2004; Röhr et al., 2005; Sanlier, 2009; Sanlier, 2010). A majority of the consumers in Netherlands have been revealed to perceive the expiry dates marked on product labeling as the storage time for food, but having no idea of the fact that such dates become ineffective, once the product's package is actually opened. It has also been observed that respondents with kids of four or lower age were more careful and attentive on food product inserts than older consumers, who preferred to follow their experience patterns when storing food presenting no or little knowledge about the storage conditions of or the newly emerging products. There was a great gap in knowledge among respondents, on methods for storing food (Terpstra et al., 2005).

Varying demographies and life styles entail to situations that make life threatening, great epidemics out of foodborne diseases, in combination with the extraordinarily dangerous species of microorganisms and highly resistant bacteria (Haapala and Probart, 2004).

The increasing need for education on food safety has just recently been noticed in the US and EU, with the early sparkles of national initiatives aimed at effectively educating the young consumers and especially the potential food preparers of the future. Consequently, the need becomes eminent in this conjuncture, for education. There is benefit in expanding the outreach of consumer educations to cover wider communities through mass media, common public and formal education starting at early childhood. It is among the fundamental duties of the government to safeguard social wealth, improve and maintain high levels of health conditions, ensure full public access to healthier and high quality foodstuffs and retain comprehensive control of food from production stage to consumption by the end user, in order to ensure physically sound and mentally healthy newer generations (Anonymous, 2001).

Besides, there is not any public authority vested with the power and responsibility to carry out the controls regarding food safety, despite the lack of legislative arrangements to govern the issue, which is alarming, in both Turkey and Kazakhstan. Therefore, this study intends to demonstrate what attitudes are adopted by consumers living both in Turkey and Kazakhstan, from different cultural and educational backgrounds, in time of purchasing, as well as their levels of knowledge on and practical use of food safety.

\section{MATERALS AND METHODS}

This study was performed between March and September 2010 on a total of 668 individuals from Turkey (348) and Kazakhstan (320), consisting of 310 males and 358 females, who had shown full consent to attend it on a voluntary basis, to compare the purchasing behaviors and levels of knowledge on food safety, in both countries. The respondents were given a short brief on the subject and purpose of this study and general rules to follow, at the beginning. Survey forms prepared for the purpose were effectively used by the authors themselves through face-to-face dialogs. The average age for respondents from Turkey and Kazakhstan were $32.87 \pm 9.60$ years and $27.72 \pm 10.96$ years, respectively.

\section{Instrumentation}

There are 30 questions aimed at determining the level of knowledge in respondents on food safety and 20 expressions intended to identify their purchasing behaviors, on scale put up by the researchers, utilizing related articles (Haapala and Probart, 2003; Unusan, 2007; Sanlier, 2009). A pilot study has been performed on a group of 50 consumers, to check whether the questions on the scale were understood or not, and the forms were then reviewed and revised, with minor changes made in unclear questions. The answers given to questions relating to food safety and purchasing behaviors were evaluated as true and false. Scoring has been made so that a "True" answer would yield one point while a "False" one return "0" point. The information questions about food safety were evaluated in a score range of $0-30$, while statements concerning purchasing behaviors covered a range of 
Table 1. Demographic informatıon of participants.

\begin{tabular}{llcccc}
\hline \multirow{2}{*}{ Demographic characteristics } & \multicolumn{2}{c}{ Turkey } & \multicolumn{2}{c}{ Kazakhstan } \\
\cline { 3 - 6 } Gender & Male & $\mathbf{n}$ & \% & $\mathbf{n}$ & $\%$ \\
\hline \multirow{2}{*}{ Marital status } & Female & 167 & 48.0 & 143 & 44.7 \\
& & 181 & 52.0 & 177 & 55.3 \\
& Single & & & & \\
& Married & 129 & 37.1 & 181 & 56.6 \\
& & 219 & 62.9 & 139 & 43.4 \\
\multirow{3}{*}{ Education } & Primary education & 48 & 13.8 & 33 & 10.3 \\
& High school & 117 & 33.6 & 110 & 34.4 \\
& Associate degree & 43 & 12.4 & 106 & 33.1 \\
& Undergraduate & 99 & 28.4 & 71 & 22.2 \\
\hline
\end{tabular}

0-20. Furthermore, the survey form was checked for reliability, as a result of which, the cronbach alpha values were found to be 0.73 on the purchasing behavior scale and 0.79 on knowledge on food safety scale.

\section{Data analysis}

The data thus obtained were evaluated using the SPSS 13.0 statistical calculations software bundle. For each answer provided to food safety knowledge and purchasing behavior inquiries, the responses given by the consumers are broken down in a table both in numbers and percentage, and comparisons made based on countries employed the $x^{2}$ test technique. The total scores were then calculated on both the food safety knowledge and purchasing behavior scales, which were subsequently subjected to comparisons between the two countries using the Student t test, with given arithmetical means $(\bar{\chi})$ and standard deviation (SD) values. Also, the food safety knowledge scores, purchasing behavior scores and ages of consumers were correlated to study the relationships in between, while Pearson correlation factor $(r)$ was used to determine the direction and level of the relations. The evaluations made took statistical significance level as 0.05 and 0.01 .

\section{RESULTS}

Total of 348 Turkish respondents with the percentage of $48.0 \%$ male, $\% 62.9$ were married and $33.6 \%$ high school graduates while the Kazakh respondents were found to be $55.3 \%$ females, $56.6 \%$ singles and $34.4 \%$ high school graduates (Table 1).

Generally speaking, the true rates in answers provided by Turkish consumers to questions on purchasing behaviors were higher than those provided by their Kazakh peers ad there was a statistically significant difference between the true answering rates based on each country $(p<0.01, p<0.05)$. An investigation of the true answering rates for statements on purchasing behavior immediately revealed that $98.3 \%$ of the Turkish consumers said "I check the product package for soundness", $98.0 \%$ said "I look at the expiry dates on labels when purchasing products", 97.7\% said "I check the cleanliness of the store or sales point where it purchase my food", $96.0 \%$ said "I check the confirmation seal of a veterinary body when buying meat", $93.4 \%$ said "No additives in foodstuffs, that is what matters", $92.5 \%$ said "I totally reject and return a product which I later discover to be defective", $92.0 \%$ said "I check if the product I bought has any adverse affects on human health", $88.8 \%$ said "I check if the product package is made of materials which would not harm or damage the contained food product", $85.9 \%$ said "I strictly follow the instructions printed on the label when storing or cooking the product", $84.8 \%$ said "I read the label information provided on packages, before I buy foodstuffs", $83.9 \%$ said "I can comfortably consume any product regardless of where and how they were prepared and whether they are hygienic or not" $81.0 \%$ said "I am ready to pay more for food products grown without the use of agricultural growth hormones", $80.2 \%$ said "Food should have good nutritional qualities, before good taste", and finally $76.1 \%$ said "I always take into account the nutritional value when I purchase food products". The above rates for Kazakh consumers have been $94.1,88.8,85.3,83.8,57.2$, 78.4, 71.9, 75.6, 79.7, 73.1, 58.1, 50.0, 61.6 and 65.9\%, respectively. There has been a statistically significant difference between the rates of accuracy of both country's in correctly identifying the true answer in statements on purchasing behavior $(p<0.01, p<0.05)$, (Table 2).

However, the true answering rates of consumers of both countries for certain statements relating to purchasing behavior were found to be considerably low. The Turkish consumers performed low and returned less correct answers to the statements "Food sold in hypermarkets and big shopping malls are of high quality" by $43.4 \%$, "Ads give all what we need to know about the product" by $40.8 \%$, "Brands always contain high quality stuff" by $36.2 \%$, "Food with higher nutritional qualities are 
Table 2. The distribution of consumers' food purchasing behavior.

\begin{tabular}{|c|c|c|c|c|c|}
\hline \multirow{2}{*}{ Statements } & \multicolumn{2}{|c|}{$\begin{array}{l}\text { Turkey } \\
(\mathrm{n}=348)\end{array}$} & \multicolumn{2}{|c|}{$\begin{array}{c}\text { Kazakhstan } \\
(\mathrm{n}=320)\end{array}$} & \multirow[t]{2}{*}{$\mathbf{P}$} \\
\hline & $\frac{\mathbf{n}}{\mathrm{n}}$ & $\%$ & $\mathrm{n}$ & $\%$ & \\
\hline I check the product package for soundness. & 342 & 98.3 & 301 & 94.1 & $0.004^{* *}$ \\
\hline I look at the expiry dates on labels when purchasing products. & 341 & 98.0 & 284 & 88.8 & $0.000^{* *}$ \\
\hline I check the cleanliness of the store or sales point where it purchase my food. & 340 & 97.7 & 273 & 85.3 & $0.000^{* *}$ \\
\hline I check the confirmation seal of a veterinary body when buying meat. & 334 & 96.0 & 268 & 83.8 & $0.000^{* *}$ \\
\hline No additives in foodstuffs, that is what matters. & 325 & 93.4 & 183 & 57.2 & $0.000^{* *}$ \\
\hline I totally reject and return a product which I later discover to be defective. & 322 & 92.5 & 251 & 78.4 & $0.000^{* *}$ \\
\hline I check if the product I bought has any adverse affects on human health. & 320 & 92.0 & 230 & 71.9 & $0.000^{* *}$ \\
\hline $\begin{array}{l}\text { I check if the product package is made of materials which would not harm or damage } \\
\text { the contained food product. }\end{array}$ & 309 & 88.8 & 242 & 75.6 & $0.000^{* *}$ \\
\hline $\begin{array}{l}\text { I strictly follow the instructions printed on the label when storing or cooking the } \\
\text { product. }\end{array}$ & 299 & 85.9 & 255 & 79.7 & $0.032^{*}$ \\
\hline I read the label information provided on packages, before I buy foodstuffs. & 295 & 84.8 & 234 & 73.1 & $0.000^{* *}$ \\
\hline $\begin{array}{l}\text { I can comfortably consume any product regardless of where and how they were } \\
\text { prepared and whether they are hygienic or not. }\end{array}$ & 292 & 83.9 & 186 & 58.1 & $0.000^{* *}$ \\
\hline $\begin{array}{l}\text { I am ready to pay more for food products grown without the use of agricultural growth } \\
\text { hormones. }\end{array}$ & 282 & 81.0 & 160 & 50.0 & $0.000^{* *}$ \\
\hline Food should have good nutritional qualities, before good taste. & 279 & 80.2 & 197 & 61.6 & $0.000^{* *}$ \\
\hline I always take into account the nutritional value when I purchase food products. & 265 & 76.1 & 211 & 65.9 & $0.004^{* *}$ \\
\hline Food sold in hypermarkets and big shopping malls are of high quality. & 151 & 43.4 & 112 & 35.0 & $0.027^{*}$ \\
\hline Ads give all what we need to know about the product. & 142 & 40.8 & 84 & 26.3 & $0.000^{* *}$ \\
\hline Brands always contain high quality stuff. & 126 & 36.2 & 101 & 31.6 & 0.205 \\
\hline Food with higher nutritional qualities are always more expensive. & 108 & 31.0 & 67 & 20.9 & $0.003^{* *}$ \\
\hline The promotional stuff (gifts) given with foodstuffs influence my purchasing decisions. & 105 & 30.2 & 90 & 28.1 & 0.561 \\
\hline The price is what drives my decision on which foodstuff to purchase. & 45 & 12.9 & 60 & 18.8 & $0.039^{*}$ \\
\hline
\end{tabular}

${ }^{*} p<0.05 ;{ }^{* *} p<0.01$.

always more expensive" by $31.0 \%$, "The promotional stuff (gifts) given with foodstuffs influence my purchasing decisions" by $30.2 \%$ and "The price is what drives my decision on which foodstuff to purchase" by $12.9 \%$. The same situation is also true for Kazakh consumers. Their true answer ratings to the above statements were found to be $35.0,26.3,31.6,20.9,28.1$ and $18.8 \%$, respectively (Table 2).

Basing on the results obtained from Table 3 , only 4 out of a total of 30 statements concerned with food safety have been found to have no significance in statistical terms, between the consumers of the two countries ( $p$ $>0.05)$. A majority (95.4\%) of Turkish respondents correctly affirmed the statement "Surfaces to be used for preparation of foodstuffs should be cleaned before operation", while only a few $(30.7 \%)$ could have managed to give a true answer to the statement "Milk sold on streets may only be used after treatment with heat for half an hour". For the Kazakh side, a majority (78.4\%) of the consumers correctly identified the statements "Peelable fruit and vegetables should be flushed with fresh running water" while only a few (12.8\%) made the correct point about the statement "Leftovers should be put inside the fridge in no later than two hours of consumption".

The true answering rates of Turkish resident consumers to questions regarding food safety were found to be higher than Kazakh consumers. For instance, Turkish consumers correctly affirmed the statements "Surfaces to be used for preparation of foodstuffs should be cleaned before operation" ( 95.4\%), "Peelable fruit and vegetables should be flushed with fresh running water" (93.7\%), "Poultry like chicken, turkey and etc. should be washed before being cooked" (93.1\%) "Hands are sources of contamination for food-borne diseases" $(92.2 \%)$, "Hands contain the most intense populations of microorganisms in a body" (89.1\%), "The bacteria passing to the food from the hands may create harmful toxins in the food" (86.5\%), "Raw food and cooked food should be stored separately" (85.1\%), "Thawed meat should not be frozen again" (83.6\%), "Food containing cans with lumps and protrusions are inconvenient for use" (83.0\%), and "Canned food may be stored in 
Table 3. Distribution of correct answer on the food safety knowledge guestionnaire.

\section{Statements concerning food safety}

Surfaces to be used for preparation of foodstuffs should be cleaned before operation.

Peelable fruit and vegetables should be flushed with fresh running water.

Poultry like chicken, turkey and etc. should be washed before being cooked.

Hands are sources of contamination for food-borne diseases.

Hands contain the most intense populations of microorganisms in a body.

The bacteria passing to the food from the hands may create harmful toxins in the food.

Raw food and cooked food should be stored separately.

Thawed meat should not be frozen again.

Food containing cans with lumps and protrusions are inconvenient for use.

Canned food may be stored in shelves of their original warehouses

Perishable foods in a short span of time should be put inside the fridge within two hours after the purchase

Cooked foods should be left at room temperature until cool

A food suspected of being corrupted can be used again after boiling.

Raw chicken, fish and meat should not contact each other.

Leftovers should be put inside the fridge in no later than two hours of consumption.

Food appearance is more important than hygiene.

Food freezing process doesn't kill bacteria, it only stops their reproduction.

Raw eggs or foods that contain raw eggs can be dangerous.

There isn't an inconvenience to the use of cracked or broken eggs.

Hard boiled egg can be kept at room temperature for more than two days.

Pasteurized milk can be stored in the fridge temperature for a maximum of 3 days in its unopened box.

Saliva contaminates the air and food while blow cigarette smoke.

Internal temperature of chicken should be high for safe cooking.

After touching raw food, you can not touch cooked food.

It should be taste milk rather than look at its expiry date to check if it is safe or not.

Wiping the used surfaces of a meat cutting board right after use with a piece of paper towel would prevent bacterial growth before the board can be used for cutting any other food product.

Food can be checked for taste to determine whether it is safe or not

Frozen meat can be thawed over counter-central heating.

A wiping cloth can be used as a cleaning material when preparing meals.

Milk sold on streets may only be used after treatment with heat for half an hour.

\begin{tabular}{|c|c|c|c|c|}
\hline \multicolumn{2}{|c|}{ Turkey (n=348) } & \multicolumn{2}{|c|}{$\begin{array}{c}\text { Kazakhstan } \\
(\mathrm{n}=320)\end{array}$} & \multirow[t]{2}{*}{$\mathbf{P}$} \\
\hline Number & $\%$ & Number & $\%$ & \\
\hline 332 & 95.4 & 238 & 74.4 & $0.000^{* *}$ \\
\hline 326 & 93.7 & 251 & 78.4 & $0.000^{* *}$ \\
\hline 324 & 93.1 & 246 & 76.9 & $0.000^{* *}$ \\
\hline 321 & 92.2 & 249 & 77.8 & $0.000^{* *}$ \\
\hline 310 & 89.1 & 206 & 64.4 & $0.000^{* *}$ \\
\hline 301 & 86.5 & 184 & 57.5 & $0.000^{* *}$ \\
\hline 296 & 85.1 & 231 & 72.2 & $0.000^{* *}$ \\
\hline 291 & 83.6 & 138 & 43.1 & $0.000^{* *}$ \\
\hline 289 & 83.0 & 220 & 68.8 & $0.000^{* *}$ \\
\hline 277 & 79.6 & 190 & 59.4 & $0.000^{* *}$ \\
\hline 275 & 79.0 & 212 & 66.3 & $0.000^{* *}$ \\
\hline 273 & 78.4 & 229 & 71.6 & $0.004^{* *}$ \\
\hline 265 & 76.1 & 145 & 45.3 & $0.000^{* *}$ \\
\hline 264 & 75.9 & 221 & 69.1 & 0.050 \\
\hline 259 & 74.4 & 41 & 12.8 & $0.000^{* *}$ \\
\hline 258 & 74.1 & 75 & 23.4 & $0.000^{* *}$ \\
\hline 252 & 72.4 & 157 & 49.1 & $0.000^{* *}$ \\
\hline 232 & 66.7 & 171 & 53.4 & $0.000^{* *}$ \\
\hline 222 & 63.8 & 145 & 45.3 & $0.000^{* *}$ \\
\hline 218 & 62.6 & 169 & 52.8 & $0.011^{*}$ \\
\hline 213 & 61.2 & 178 & 55.6 & 0.144 \\
\hline 209 & 60.1 & 190 & 59.4 & 0.857 \\
\hline 206 & 59.2 & 56 & 17.5 & $0.000^{* *}$ \\
\hline 178 & 51.1 & 153 & 47.8 & 0.389 \\
\hline 177 & 50.9 & 81 & 25.3 & $0.000^{* *}$ \\
\hline 152 & 43.7 & 75 & 23.4 & $0.000^{* *}$ \\
\hline 151 & 43.4 & 60 & 18.8 & $0.000^{* *}$ \\
\hline 145 & 41.7 & 83 & 25.9 & $0.000^{* *}$ \\
\hline 123 & 35.3 & 56 & 17.5 & $0.000^{* *}$ \\
\hline 107 & 30.7 & 68 & 21.3 & $0.005^{\star *}$ \\
\hline
\end{tabular}

${ }^{*} p<0.05 \quad$ ** $p<0.01$.

shelves of their original warehouses" (79.6\%). The true answering rates for the above questions, of Kazakh consumers have been $74.4,78.4,76.9,77.8,64.4,57.5$, $72.2,43.1,68.8$ and $59.4 \%$, respectively. There has been a statistically significant difference between the rates of accuracy of both country's in correctly identifying the true answer to above statements on food safety $(p<0.01)$, (Table 3).
Some of the statements on food safety were correctly answered by the consumers from both countries by less than $50 \%$. While Turkish consumers correctly assessed the statements "Wiping the used surfaces of a meat cutting board right after use with a piece of paper towel would prevent bacterial growth before the board can be used for cutting any other food product" (43.7), "Food can be checked for taste to determine whether it is safe or 
Table 4. Knowledge of food safety and purchasing behavior score according to countries.

\begin{tabular}{llcccc}
\hline Variables & & Mean & Standard deviation & t test & P value \\
\hline \multirow{2}{*}{ Purchasing behavior scores } & Turkey $(\mathrm{n}=348)$ & 14.43 & 2.56 & \multirow{2}{*}{12.197} & \multirow{2}{*}{$0.000^{\star *}$} \\
& Kazakhstan $(\mathrm{n}=320)$ & 11.84 & 2.92 & & \\
& & & & & \\
\multirow{2}{*}{ Food safety knowledge scores } & Turkey $(\mathrm{n}=348)$ & 20.82 & 4.20 & 19.400 & $0.000^{\star *}$ \\
& Kazakhstan $(\mathrm{n}=320)$ & 14.74 & 3.86 & \\
\hline
\end{tabular}

${ }^{* *} p<0.01$

Table 5. Correlation between age, participant scores of food safety knowledge and purchasing behavior ( $r$ ).

\begin{tabular}{lcc}
\hline Variables & Purchasing behavior scores & Food safety knowledge scores \\
\hline Food safety knowledge scores & $0.541^{\star \star}$ & \\
\hline Age & $0.325^{\star \star}$ & $0.148^{* \star}$ \\
\hline${ }^{* \star} p<0.01$. & & \\
\end{tabular}

not" (43.4\%), "Frozen meat can be thawed over countercentral heating" (41.7\%), "A wiping cloth can be used as a cleaning material when preparing meals" (35.3\%) and "Milk sold on streets may only be used after treatment with heat for half an hour" (30.7\%) the Kazakh side's rate of accuracy in providing the right answers have been $23.4,18.8,25.9,17.5$ and $21.3 \%$, respectively. There has been a statistically significant difference between the rates of accuracy of both country's in correctly identifying the true answer to above statements on food safety $(p<0.01)$, (Table 3).

While the Turkish consumers scored $14.43 \pm 2.56$ for purchasing behavior and $20.82 \pm 14.74$ for food safety knowledge tests, their Kazakh peers performed $11.84 \pm$ 2.92 and $14.74 \pm 3.86$, respectively. The difference between the two study groups were found to be statistically significant $(p<0.01)$.

Finally, the purchasing behavior score of the consumers were analyzed as compared to their food safety knowledge scores and relations between their ages, and the resultant findings compiled into Table 5 .

A positive and statistically significant correlation $(r=0.148, p<0.01)$ was found to exist between the food safety knowledge and purchasing behavior scores $(r=0.541, \quad p<0.01)$, ages and purchasing behaviors $(r=0.325, p<0.01)$ and food safety knowledge scores and ages of the consumers.

\section{DISCUSSION}

When consumers purchase foodstuffs, they guide the way in which the food safety system operates to the extent of the selectivity and rationalism reflected by their attitudes. In addition, they demand all standardscompliant, reliable, healthy and inexpensive food items and thereby ensure that food production plants and outlets operate in compliance with applicable laws on food, international norms and standards. Aware consumers also set the quality of food inspection ad controls conducted by the government to protect them. Consumers group after becoming aware individuals to form into non-governmental organizations to enforce and ensure the effective operation of the food safety system, while pressing the government to enact laws for the protection of consumer rights (Dağ and Merdol Kutluay, 1999).

Albayrak (2000) and Kucukkose (2002) found that consumers mostly check the product expiry dates, production dates and overall packing of foodstuffs, whether the packages are recyclable or not, type and quality of the material in which they are manufactured, their suitability for containing food and the state of soundness they present. Kolodinsky et al. (2008) observed that price is the topmost motivator of food purchasing behaviors and that the energy, nutritional elements and especially the amount of fat in the food as stated on product label have more or less influence on the choices of consumers. Alpoguz et al. (2009) have found in a study they performed on students that the students would never regard whether the expiry dates are overdue or packages are opened, when they buy foodstuffs, however, almost half of the youth never read information provided on product labels when purchasing packed food. Another study conducted in Italy showed that the relatively expensive sale prices of vegetables and fruit grown through organic farming methods influence the will to buy, in the consuming public, to purchase such products, due to low income levels (Boccaletti and Nardella, 2000). The contemporary changes in the areas of education, communication and technology also reflect on purchasing behaviors among 
the consumer public, changing their nutritional habits and cultures as a result of changes in the social culture caused by globalization (Öztop and Babaoğul, 2004). The dazzling urbanization rates, vast diversification of products, ads communicated through mass media, rise in the per capita average income and women's integration into the business life affect the perspective and perception of food products in the consumer and therefore the purchasing behaviors. A consumer check of the food product in time of buying is essential for protecting the health of the consumer, while preventing him or her from being deceived economically. This study has revealed the need on the part of consumers living in both countries for having access to educational facilities to improve their inefficient purchasing behaviors in a more cautious manner, despite the fact that Turkish consumers appear to be more aware about the food purchasing behaviors (Table 2).

Lack of food safety entails to territorial and global problems. Food-borne diseases are frequently seen and reported in almost any country whether advanced or underdeveloped, although they differ more or less from one country to another, depending on social life styles and economic conditions (Unusan, 2007; Sanlier, 2009). It is crucial that conditions of hygiene are ensured in all processes through production to customer offering of foodstuffs, while keeping the consumer public well informed about the supply and use of safe food. Therefore, the accessibility of food should be handled as one and common concern with all its integrity, and the entire process from production to marketing through the distribution network should be brought under permanent control (Anonymous, 2001). The urgent need for protecting and preserving the health of consumer in terms of balanced and sufficient food consumption, which is a critical factor in people's gaining and retaining the ability to live, raise and age completely free of any immediate threats of diseases by consuming reliable (healthy) and quality food products and protection against all kinds of deceit when purchasing food highlight to the significance of the matter (Trepka et al., 2006).

Roseman and Kurzynske, in a study they performed recently (2006), found that age, sex, income and educational levels all influence the food safety knowledge and behaviors of the consumers. Other studies performed show that more information and higher perception is possessed in women then men (Bruhn and Schutz, 1999; Bryd-Bredbenner et al., 2008) and in adults than youth (Sanlier, 2009) in terms of food safety. Another study demonstrates that there is insufficient knowledge among the consumer public on food-borne diseases, hand-washing routines, purchasing food, separating raw and cooked food, thawing and cooling of frozen food and consumption of raw eggs and therefore, the obvious need for consumers to undertake education on food safety (Surujlal and Badrie, 2004). It has been reported in a study conducted with the aim to determine knowledge, attitudes and behaviors on food-borne diseases and food processing practices of Italian Mothers, that $36.0 \%$ of the moms studied knew or heard about pathogenic microorganisms. It was also observed that level of educatedness is an indicator of this knowledge and older and more educated women among the respondents have shown a positive attitude and approach to food-borne diseases at a high degree (Angelillo et al., 2001). In another study examining the food safety knowledge and attitudes of consumers, it was clearly shown that a majority of consumers were lacking any information about typhoid, gastro-intestinal inflammation and amebiasis, despite being knowledgeable in such food-borne diseases as cholera, food poisoning and jaundice (Sanlier et al., 2010). In a further study performed on US consumers, it was found tat consumers were especially clueless about microorganisms that cause food-borne diseases and foodstuffs being under threat of these microorganisms (Wilcock et al., 2004).

A recent study attempted to assess the level of knowledge in 904 consumers on food preparation and storage techniques both before and after a one week long education, using the survey method. The resultant findings revealed that knowledge of consumers were incomplete and faulty for the most part, while the rate of wrong information dropped after the education. For example, while only $31.7 \%$ of the respondents revealed knowledge of the fact that fridge temperature should be maintained in a range of 0 to $40^{\circ} \mathrm{C}$, this rate grown to $78.4 \%$ after education. Besides, the numbers of people who had stored raw meat and cooked food in a wrong way in their refrigerators were declined to 63 and $65 \%$, from a baseline of 144 and 133, before the education (Ghebrehewet and Stevenson, 2003). As this study clearly suggests education on food safety has a great influence on the consumer. Earlier studies also demonstrated the need in consumers for education on food safety (Bruhn and Schutz, 1999, Wilcock et al., 2004; Medeiros et al., 2004; Baş et al., 2006; Unusan, 2007). Most of the consumers in Italy recognize Staphylococcus Aureus (92.9\%) and Colostridium botulinum (87.5\%) as food-borne pathogens. A $53 \%$ of the consumers believe that instant food would elevate he risk for food poisoning. The ratio of people knowing the requirement to separate raw food from cooked ones to those not knowing is $84.6 \%$. A $90.4 \%$ of the consumers know that thawed food should never be frozen again (Angelillo et al., 2001). In another study, knowledge of Turkish consumers about meat purchase, storage, preparation, cooking and serving in the domestic kitchen were investigated and it was found that many individuals failed to store meat at the correct temperature or did not defrost meat correctly. It was also reported that food handling practices differed according to socioeconomic group and the level of education of the consumers were noted (Karabudak, Bas and Kızıltan, 2008). In addition 
to the survey studies concerning food safety, there have been also some observation based studies, where people are found to not follow many food safety rules when preparing meals. A $97 \%$ of the individuals volunteering the study has indicated that they would wash their hands with soap under running water, before preparing food. A $89 \%$ of the individuals who stated that meat cutting boards should be washed through with flushing water and soap, although only $60 \%$ were putting this practice in everyday life (Bermudez-Millan et al., 2004). A study conducted in the US showed that although $86 \%$ of the consumer public are aware of the fact that hand-washing practice prevent food poisoning, only $66 \%$ actually washed their hands and only after touching raw meat and poultry flesh (Wilcock et al., 2004 ).

At the end of this study, it was found that Turkish consumers had better levels of knowledge and information about food safety than their counterparts in Kazakhstan, but they still were below the sufficient levels (Tables 3 to 5). Although food safety lyes within the common authoritative and responsibility frames of the government, the food industry and the consumer, greater burden falls upon the government as the ultimate body responsible for setting and enforcing legal arrangements covering the food sector (Soydal, 1999). Governments have to establish an environment that, in addition to ensuring social, political and economic stability and justice, would bring peace and develop appropriate policies accordingly. With a global view, active cooperation seems a must between world governments inter alias and with UN institutions, financial institutions, intergovernmental organizations and non-governmental organizations to ensure food safety for all (Özel, 2003). The first measure to take and initial step toward performing a risks analysis in the field of food safety should be to educate consuming public on food safety. Savvy consumers present a motivating power for producers and industrialists in producing safe foodstuffs and for the government in establishing wide and effective control over food. Not only the food producers but also the food industrialists should assume offering safe food to consumer public as a social liability.

Misinformation of the public on food safety should be prevented. Professionals scientists and media should assume responsibility for this matter. The results obtained from the present study brings highlight to the importance of education once again, for which reason, there is a felt need to educate the consuming public on food safety. The data gathered from this study have revealed that there is an urgent need for food safety education in this target group. An effective food safety education program should cover information concerning temperature control of food, proper food preparation practices, prevention of cross contamination, suitable clean up procedures, causative foodborne illness agents, high risk groups, and other contributing factors to foodborne diseases and prevention strategies (Osaili et al., 2011). However, means should be provided to help seeding messages that any food safety education program would deliver in the minds of the consumers.

Following its completion, the education instructions should be repeated at regular intervals to ensure that knowledge learned throughout the classes entail to attitude and attitude results in behavior, with assurance of the continuity of education through surveillance controls. It is of common belief and opinion of the authors of this study that common research and studies to be performed through increasing cooperation between Turkey and Kazakhstan, two countries with a common past and culture would contribute much to raising public awareness. In the meanwhile, proper inclusion should be given to ensuring food safety in action plans, inter sectoral cooperation should be developed between the industries of both countries and efforts to be pursued in that context should gain effectiveness and speed in both states.

\section{REFERENCES}

Albayrak M (2000). Ankara ilinde gıda maddeleri paketleme ve etiketleme bilgileri hakkında tüketicilerin bilinç düzeyinin ölçülmesi, gıda maddeleri alım yerleri ve ambalaj tercihleri üzerine bir çalışma. Ankara: Burcu Ofset Matbaacılık.

Alpuğuz G, Erkoç F, Mutluer B, Selvi M (2009). Gençlerin (14-24 yaş) gıda hijyeni ve ambalajlı gıdaların tüketimi konusundaki bilgi ve davranışlarının incelenmesi. Türk Hijyen ve Deneysel Biyoloji Dergisi, 66(3): 107-115.

Angelillo IF, Foresta MR, Scozzafava C, Pavia M (2001). Consumers and foodborne diseases: Knowledge, attitudes and reported behavior in one region of Italy. Int. J. Food Microbiol., 64: 161-166.

Angelillo IF, Viggiani NMA, Rizzo L, Bianco A (2000). Food handlers and foodborne diseases: Knowledge, attitudes and reported behavior in Italy. J. Food Prot., 63(3): 381-385.

Anonymous (2001). Ulusal Gıda ve Beslenme Stratejisi çalışma grubu Rapor, Ankara DPT, Yayın No. 2632.

Baş, M (2004). Besin Hijyeni Güvenliği ve HACCP. I. Baskı, Sim Matbaacılık Ltd. Sti., Ankara.

Baş M, Ersun AŞ, Kıvanç G (2006). The evaluation of food hygiene knowledge, attitudes, and practices of food handlers in food businesses in Turkey. Food Control, 17: 317-322.

Bermudez-Millan A, Pérez-Escamilla R, Damio G, González A, SeguraPérez S(2004). Food safety knowledge, attitudes and behaviors among Puerto Rican Caretakers living in Hartford Connecticut. J. Food Prot., 67(3): 512-516.

Boccaletti S, Nardella M (2000). Consumer wilingness to pay for pesticide-free fresh fruit and vegetables in Italy. IAMR, 3: 297-310.

Bruhn CM, Howard H, Schutz G (1999). Consumer food safety knowledge and practices. JFS, 19: 73-87.

Byrd-Bredbenner C, Abbot CM, Wheatley V, Schaffner D, Bruhn C, Blalock $L$ (2008). Risky eating behaviors of young adults-ımplications for food safety education. JADA, 108: 549-552.

Dağ A, Merdol TK (1999). Toplu beslenme servislerinde çalışan personel için geliştirilen hijyen eğitim programının bilgi, tutum ve davranışlara etkisi. Beslenme ve Diyet Dergisi, 28: 47-51.

Eren S (2007). Türk Mutfağı ve HACCP Sistemi; Mutfak personelinin HACCP bilgilerinin ölçülmesi. I. Ulusal Gastronomi Sempozyumu ve Sanatsal Etkinlikler 4-5 Mayıs, Antalya.

Ghebrehewet S, Stevenson L (2003). Effectiveness of home-based food storage training: a community development approach. IJEHR, 13: $169-174$.

Haapala I, Probart C (2004). Food safety knowledge perceptions and behaviors among middle school students. JNEB, 36: 71-76. Karabudak E, Bas M, Kiziltan G (2008). Food safety in the home consumption of meat in Turkey. Food Control, 19(3): 320-327.

Knight P, Jackson J, Bain B, Shearer DE (2003). Household food safety awareness of selected urban consumers in Jamaica. Int. J. Food. Sci. 
Nutr., 54(4): 309-320.

Kolodinsky J, Green J, Michahelles M, Harvey-Berino M, Jean R. (2008). The use of nutritional labels by college students in a foodcourt setting. J. Am. Coll. Health, 57(3): 297-301.

Küçükköse Ş (2002). Farklı Öğrenim Düzeyindeki Tüketicilerin Süpermarketlerden Gıda Alışverişlerinde Etkilendikleri Faktörler. Ankara: Gazi Üniversitesi Eğitim Bilimleri Enstitüsü Aile Ekonomisi ve Beslenme Anabilim Dalı Yüksek Lisans Tezi.

Mead P, Slutsker L, Dietz V, McCaig LF, Bresee JS, Shapiro J, Griffin PM, Tauxe RV (1999). Food-related illness and death in the United States. EID, 5(5): 607-625.

Jevsnik M, Hlebec V, Raspor P (2008). Consumers' awareness of food safety from shopping to eating. Food Control, 19: 737-745.

Knabel SJ (1995). Foodborne illness: role of home food handling practices (scientific status summary). Food Technol., 49: 119-131.

Mederios L, Hillers V, Kendall P, Mason A (2001). Evaluation of food safetyeducation for consumers. JNEB, 33(S1): S27-S34.

Meer RR, Misner SL (2000). Food safety knowledge and behavior of expanded food and nutrition education program participants in Arizona. J. Food Prot., 63: 1725-1731.

Medeiros L, Hillers VN, Gang C, Bergmann V, Kendall P, Schroeder $M$ (2004). Design and development of food safety knowledge and attitude scales for consumer food safety education. JADA, 104: 11.

Mitakakis TZ, Sinclair M I, Fairley C K, Lightbody PK, Leder K, Hellard ME (2004). Food safety in family homes in Melbourne, Australia. J. Food Prot., 66 (4): 8181-822.

Özel L (2003). Ortadoğu Ülkelerinin Gıda Güvenliği ve Gıda Politikaları. Yüksek Lisans Tezi. Hacettepe Üniversitesi, Sosyal Bilimler Enstitüsü. Ankara.

Öztop H, Babaoğul M (2004). Sosyo-ekonomik değişimler ve tüketim eğilimine etkisi. Standard, 43(511): 71-78.

Redmond E C, Griffith J (2003). Consumer food handling in the home: A review of food safety studies. J. Food Prot., 66: 130-161.
Rosemen M, Kurzynske J (2006). Food safety perceptions and behaviors of Kentucky consumer. J. Food Prot., 69(6): 1412-1421.

Röhr A, Lüddecke K, Drusch S, Müler MJ Alvensleben RV (2005). Food quality and safety consumer perception and public health concern. Food Control, 16: 649-655.

Sanlier N (2009). The knowledge and practices of food safety by young and adult consumers. Food Control, 20: 538-542.

Sanlier N, Cömert M, Durlu-Özkaya F (2010). Hygiene perception conditions of hotel kitchen staff in Ankara, Turkey. JFS, 30: 415.

Soydal F (1999). Gıda güvenliği, risk değerlendirme. Gıda Dergisi, Ekim, pp. 63-65.

Surujlal M, Badrie N (2004). Household consumer food safety study in Trinidad, West Indies. IJFS, 3: 8-14.

Trepka MJ, Murunga V, Cherry S, Huffman FG, Dixon Z (2006). Food safety beliefs and barriers to safe food handling among WIC program clients, Miami, Florida. JNEB, 38: 371-378.

Terpstra MJ, Steenbekkers LPA, de Maertelaere NCM, Nijhuis S (2005). Food storage and disposal: Consumer practices and knowledge. BFJ, 107(7): 526-533.

Unusan N (2007). Consumer food safety knowledge and practices in the home in Turkey. Food Control, 18: 45-51.

WHO (2002). Food Safety Issues: WHO Global Strategy for food safety. http://www.who.int/foodsafety/publications/general/en/strategy_en.pdf (04.02.2010).

Wilcock A, Pun MM, Joseph JK, Aung M (2004). Consumer attitudes, knowledge and behaviour: A review of food safety issues. Trends. Food. Sci. Technol., 15: 56-66.

Woodburn M J, Raab C A (1997). Household food preparers' foodsafety knowledge and practices following widely publicized outbreaks of foodborne illness. J. Food Prot., 60: 1105-1109.

Osaili, TM, Obeidat, BA, Abu Jamous, DO, Bawadi, HA (2011). Food safety knowledge and practices among college female students in north of Jordan. Food Control, 22(2): 269-276. 